\title{
Type I C1 Inhibitor Deficiency with a Small Messenger RNA Resulting from Deletion of One Exon
}

\author{
Tadashi Ariga," Takashi Igarashi, Narayanaswamy Ramesh," Richard Parad,“ Marco Cicardi,' and Alvin E. Davis III* \\ *Department of Pediatrics, Harvard Medical School, and Divisions of Immunology and Nephrology, The Children's Hospital, Boston, \\ Massachusetts 02115; ' Department of Pediatrics, The Hospital of the Tokyo University, Tokyo, Japan; and \\ ${ }^{\S}$ Cattedra di Clinica Medica Universita di Milano, Ospedale S. Paolo, Milan, Italy
}

\begin{abstract}
The molecular genetic basis of $\mathrm{Cl}$ inhibitor (C1 INH) deficiency in a patient with type $I$ hereditary angioneurotic edema was studied. This patient was found to have an abnormally short C1 INH mRNA together with a normal message. Restriction fragment length polymorphism of the C1 INH gene was detected by Southern blot analysis of the patient's DNA after digestion with Pst I or Sac I, and hybridization with a full-length C1 INH cDNA. Hybridization of the same blot with three different fragments of the full-length CDNA suggested that exon VII and portions of both flanking introns were deleted in the C1 INH gene. Northern blot analysis of RNA from cultured monocytes, using a probe corresponding to exon VII, also indicated that the abnormal C1 INH mRNA had a deletion of these nucleotides. To confirm the hypothesis that the short C1 INH mRNA contained a deletion, the involved segment of the patient's C1 INH mRNA was amplified using the polymerase chain reaction (PCR). PCR amplification yielded two C1 INH DNA fragments of different lengths (380 and 160 bp). Southern blot and sequence analysis of both DNA fragments clearly revealed that the smaller 160-bp DNA was derived from the abnormal message and had a deletion of nucleotides corresponding to exon VII.
\end{abstract}

\section{Introduction}

Hereditary angioneurotic edema (HANE) ${ }^{1}$ is a genetic disease resulting from heterozygous deficiency of the inhibitor of the first component of complement $(\mathrm{C} 1 \mathrm{INH})(1,2)$. The disease is therefore inherited as an autosomal dominant trait, and is characterized clinically by recurrent, acute, local edema of the skin or mucosa $(3,4)$. Before androgen therapy for HANE was instituted (5), death from laryngeal edema was common $(3,4)$. The disease may be divided into two types. In type I, a normal $\mathrm{C} 1 \mathrm{INH}$ protein is present in plasma at reduced levels of from 5 to $30 \%$ of normal. Type II is characterized by normal-to-ele-

Address reprint requests to Dr. Alvin E. Davis III, Division of Immunology, The Children's Hospital, 300 Longwood Avenue, Boston, MA 02115.

Received for publication 29 November 1988 and in revised form 13 February 1989.

1. Abbreviations used in this paper: $\mathrm{Cl}$ INH, $\mathrm{Cl}$ inhibitor; HANE, hereditary angioneurotic edema; PCR, polymerase chain reaction; RFLP, restriction fragment length polymorphism.

J. Clin. Invest.

(c) The American Society for Clinical Investigation, Inc. 0021-9738/89/06/1888/06 $\$ 2.00$

Volume 83, June 1989, 1888-1893 vated antigenic levels of $\mathrm{Cl}$ INH due to the presence of a dysfunctional mutant protein, together with low levels of the normal protein $(6,7)$. Previous findings, including in vitro synthesis of $\mathrm{Cl}$ INH by cultured monocytes (8), metabolic turnover of $\mathrm{Cl}$ INH (9), and analysis of restriction fragment length polymorphism (RFLP) (10) were consistent with the hypothesis that patients are heterozygous for the defect. Genetic analysis of HANE indicates that the molecular genetic defects responsible for $\mathrm{Cl}$ INH deficiency are heterogeneous, as are those responsible for many other genetic diseases (11-14). Analysis of mutant proteins from type II HANE patients provided the first evidence for genetic heterogeneity: the proteins from different families differ in electrophoretic mobility, size, and function $(6,15,16)$. Evaluation of the C1 INH gene by Southern blot analysis in both types of HANE has revealed RFLP in 10-15\% of kindred (10). All of the RFLPs cosegregated with the disease and were different from one another. At least three variations in C1 INH mRNA have also been described. $\mathrm{C} 1 \mathrm{mRNA}$ levels in cultured monocytes from most patients with type I HANE are $\sim 50 \%$ of normal (8). Three patients with markedly elevated message levels have been detected (17) and one patient with an abnormal Cl INH mRNA has been described (8). This patient had, in addition to a normal-appearing message of $2.1 \mathrm{~kb}(18)$, a $0.2-\mathrm{kb}$ smaller mRNA that also specifically hybridized with a C1 INH cDNA probe (8).

In this study, we have analyzed the molecular genetic defect in this patient and revealed that the patient's short $\mathrm{Cl}$ INH mRNA resulted from a deletion of nucleotides corresponding to exon VII. This abnormality is derived from a deletion of exon VII, together with portions of both flanking introns, in the $\mathrm{Cl}$ INH gene.

\section{Methods}

Patient. We studied a patient with type I HANE, who has been reported previously (8). The patient had an abnormal 1.9-kb C1 INH mRNA, in addition to a normal-appearing 2.1-kb message. She had two siblings, one of whom had HANE. The sibling with HANE had the same abnormality, whereas the normal sibling had only normal appearing message. There are no other family members available for study.

Preparation of genomic DNA and Southern blot analysis. White blood cells were isolated from peripheral blood and high molecular weight genomic DNA was extracted as previously described (19). DNA was quantified by absorbance at $260 \mathrm{~nm}$, and $7.5 \mu \mathrm{g}$ of DNA was digested with restriction enzymes (Bam HI, Hind III, Pst I, Pvu II, Sac I) (New England Biolabs, Beverly, MA). DNA samples were separated by electrophoresis on $\mathbf{0 . 8 \%}$ agarose gels (Bethesda Research Laboratories, Gaithersburg, MD) and blotted onto nitrocellulose (Millipore Corp., Bedford, MA) after treatment according to Wahl et al. (20). Prehybridization and hybridization were carried out at $42^{\circ} \mathrm{C}$ in a mixture containing $50 \%$ formamide. The $\mathrm{Cl}$ INH cDNAs used as probes 
were as follows: a full-length probe consisting of nucleotides $1-1,810$, kindly provided by Dr. Susan Bock (Temple University School of Medicine, Philadelphia, PA) and numbered according to reference 21; a probe consisting of nucleotides 1-131, derived from Bam HI digestion of the full-length probe; a probe consisting of nucleotides 1,1141,284, derived from Kpn I/Eco RI digestion of the full-length probe; a probe consisting of nucleotides 1,289-1,810, derived from Eco RI digestion of the full-length probe. The probe 1,114-1,284 corresponds to nucleotides included within exon VII, and probe $1,289-1,810$ corresponds to exon VIII (22). Labeling of the probes was achieved using the oligolabeling method (23) (Oligolabeling Kit; Pharmacia Fine Chemicals, Piscataway, NJ) using alpha $\left[{ }^{32}\right.$ P]dCTP (Amersham Corp., Arlington, IL). Hybridization patterns were visualized by autoradiography.

Preparation of RNA and Northern blot analysis. Total cellular RNA was isolated from adherent monocyte monolayers (24) by lysis with guanidium thiocyanate and centrifugation through cesium chloride density gradients (25). RNA was quantitated by absorbance at $260 \mathrm{~nm}$. $10 \mu \mathrm{g}$ of total RNA was denatured with formaldehyde and formamide and separated by electrophoresis in formaldehyde-containing $1 \%$ agarose gel. Samples were transferred to nitrocellulose filters and hybridized with ${ }^{32} \mathrm{P}$-labeled probes (26).

Amplification of the abnormal mRNA segment using the polymerase chain reaction $(P C R)(27,28)$. $\mathrm{CDNA}$ used for $\mathrm{PCR}$ was synthesized from the patient's monocyte RNA $(10 \mu \mathrm{g})$ and from RNA derived from the hepatoma cell line, Hep G2 (29). Synthesis of cDNA followed the protocol supplied with the cDNA synthesis kit (Amersham Corp.). Two oligonucleotides for PCR primers were synthesized with DNA synthesizer (model 280B; Applied Biosystems, Foster City, CA). Both primers were 30 bases long. The primer sequences were based on nucleotide sequences on each side of the putative deletion and separated from this site by $\sim 50$ nucleotides. One nucleotide corresponded to nucleotides $984-1,013$ in the $\mathrm{Cl} \mathrm{INH}$ cDNA, and the other was complementary to nucleotides $1,335-1,364$. PCR amplification of synthesized $\mathrm{C} 1$ INH cDNA was performed using Taq DNA polymerase following the protocol described in the DNA amplification reagent kit (Gene Amp, Perkin-Elmer Cetus, Norwalk, CT). The cycle of denaturation, annealing, and extension was repeated 25 times. Amplified cDNA was visualized on a composite gel of $3 \%$ NuSieve and $1 \%$ SeaKem agarose (FMC Bioproducts, Rockland, ME) (30).

DNA sequencing. Amplified cDNA was subcloned into M13 mp18 (Pharmacia Fine Chemicals) and DNA sequence analysis was carried out by the modified dideoxy chain termination method of Sanger (DNA sequencing kit; Pharmacia Fine Chemicals) (31).

\section{Results}

Southern blot analysis. RFLP of the C1 INH gene was detected on Southern blot analysis of the patient's DNA after digestion with Pst I or Sac I, and hybridization with the full-length C1 INH cDNA $(1-1,810)$ (Fig. 1). No RFLP was observed with any of the other restriction endonucleases. The patient's DNA revealed a 6.9-kb band after digestion with Sac I and a 1.8-kb band after digestion with Pst I, neither of which was seen with DNA from control individuals. These bands were less intense than the other major bands. In addition to the diminished intensity of the polymorphic bands, one or more of the other DNA fragments in each digest appeared approximately half as intense as the equivalent band(s) from control DNA (the 2.9$\mathrm{kb}$ band with Pst I digestion, the 5.8- and 3.2-kb with Sac I digestion, and the 2.7-kb with Pvu II digestion). To begin to localize the mutation responsible for the RFLP; three different fragments of the full-length cDNA were used as probes. Using probe 1-131, no RFLP was detected with any restriction enzyme and all hybridized bands were the same intensity as the equivalent bands in normal individuals (Fig. $2 A$ ). Using probe

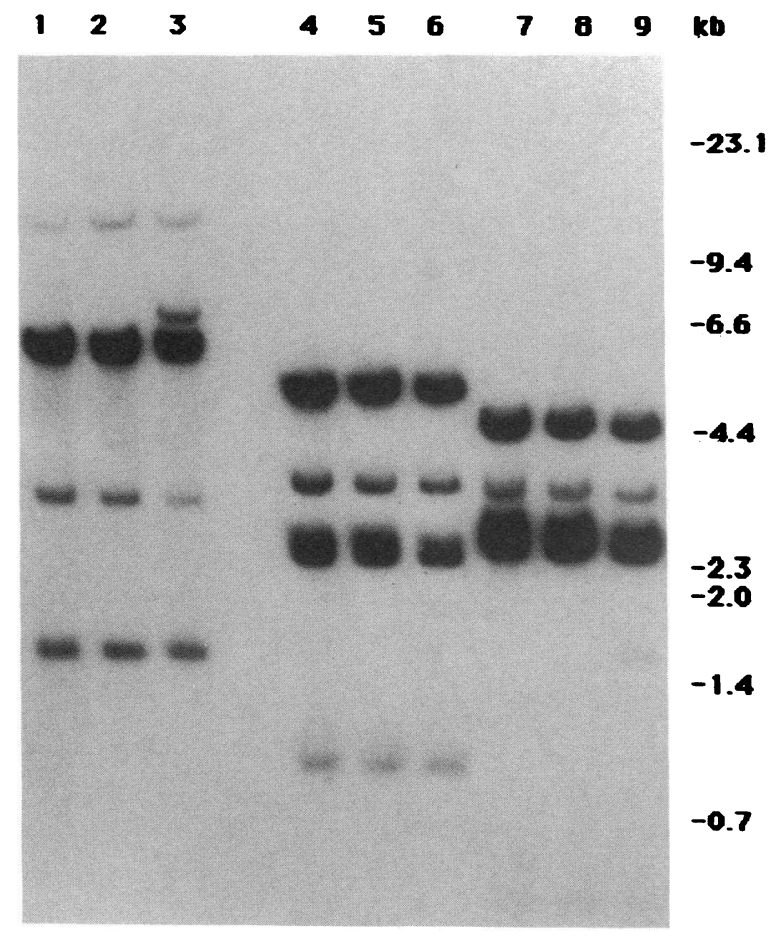

Figure 1. Southern blot analysis of high molecular weight DNA from normal individuals (lanes $1,2,4,5,7$, and 8 ) and the patient (lanes 3, 6, and 9). DNA samples were digested with Sac I (lanes 1-3), Pvu II (lanes 4-6), and Pst I (lanes 7-9) and hybridized with the fulllength $\mathrm{Cl}$ INH probe $(1-1,810)$.

$1,114-1,284$, which is entirely included within exon VII (22), no RFLP was detected, but the hybridized bands all were less intense than the equivalent bands in normal individuals (Fig. 2 $B)$. Hybridization with probe $1,289-1,810$, which is derived from exon VIII (22), again revealed RFLP's after digestion with Pst I and Sac I (Fig. $2 C$ ). It therefore seemed likely that the 6.9-kb Sac I fragment resulted from a mutation affecting both the 5.8- and 3.2-kb fragments (Fig. 1, lane 3, and Fig. 2, $B$ and $C$, lane 2). The 1.8-kb Pst I fragment appears to be derived from the 2.9-kb band (Fig. 1, lane 9, Fig. 2, B, lane 6, and Fig. $2 C$, lane 4).

Northern blot analysis. Two probes, the full-length C1 INH cDNA (1-1,810) and probe 1,114-1,284 (exon VII), were used for hybridization with Northern blots of the patient's monocyte-derived mRNA. The full-length cDNA probe hybridized with both the normal 2.1- and abnormal 1.9-kb C1 INH mRNA, as previously described (8) (Fig. 3, lane 1). Probe 1,114-1,284 hybridized only with the $2.1-\mathrm{kb}$ normal C1 INH message (Fig. 3, lane 2). This suggests that the abnormal 1.9-kb mRNA results from a deletion that includes at least nucleotides 1,114-1,284.

PCR amplification of the abnormal $m R N A$ segment. To confirm the hypothesis that the 1.9-kb Cl INH mRNA contained a deletion, the involved segment (nucleotides 984-1,364) of the patient's C1 INH mRNA was amplified using the PCR. PCR amplification of $\mathrm{mRNA}$ isolated from the hepatoma cell line, Hep G2, yielded a single amplified DNA band, which was $\sim 380 \mathrm{bp}$ in size, as expected (Fig. 4, lane 1 ). However, PCR amplification using the patient's mRNA resulted in the synthesis of two DNA bands (Fig. 4, lane 2). One 

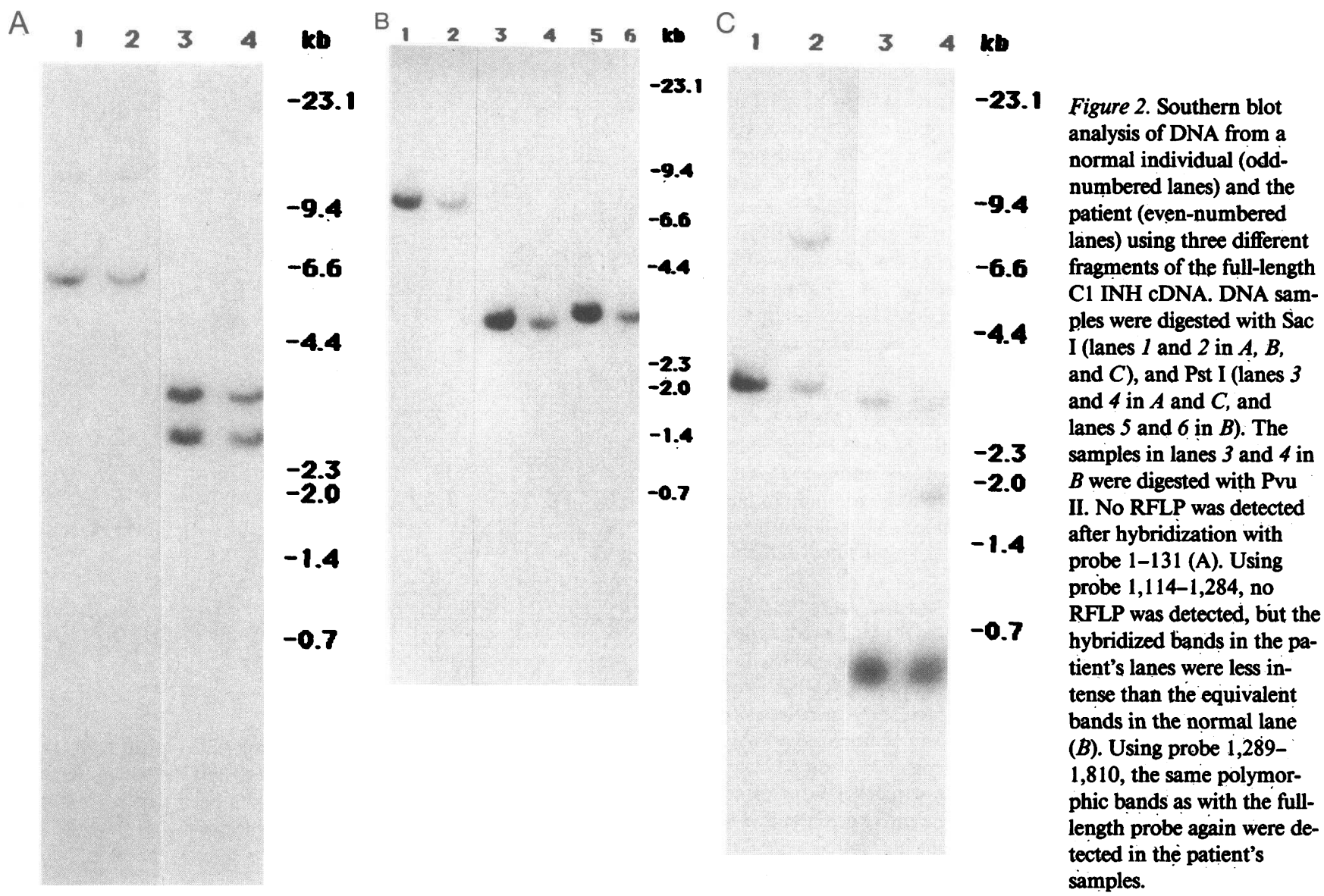

of the DNA bands was identical in size to that derived from the Hep G2 mRNA and the other was only $160 \mathrm{bp}$ long. These data further indicate that the 1.9-kb C1 INH mRNA resulted from a deletion of $\sim 220 \mathrm{bp}$. Both amplified DNA fragments hybridized with the full-length $\mathrm{Cl}$ INH cDNA, whereas only the larger DNA hybridized with probe 1,114-1,284. (data not shown).

Nucleotide sequence analysis of the two CI INH DNA fragments synthesized using PCR. The DNA sequence of the larger DNA was identical to the normal C1 INH cDNA from nucleotide 984 to 1364 . The sequence of the smaller DNA

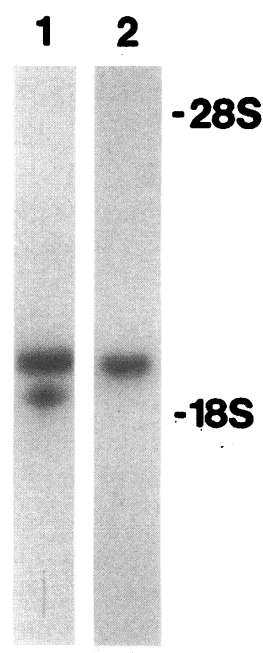

Figure 3. Northern blot analysis of RNA from the patient's monocytes. Two different sizes of $\mathrm{Cl}$ INH mRNA hybridized with the C1 INH full-length cDNA probe $(i-1,810)$ (lane 1), but only the larger message (2.1 kb) hybridized with probe 1,114-1,284. $18 \mathrm{~S}$ and $28 \mathrm{~S}$ indicate the positions of $18 \mathrm{~S}$ and $28 \mathrm{~S}$ ribosomal RNA.

showed that nucleotides 1,065-1,284 were deleted (Fig. 5). These nucleotides correspond exactly to the sequence of exon VII $(21,22)$. There was no other abnormal nucleotide sequence in the smaller DNA. Thus, the $3^{\prime}$ end of exon VI (nucleotide 1,064$)$ is spliced directly to the $5^{\prime}$ end of exon VIII (nucleotide 1,285).

\section{Discussion}

This study clearly demonstrates that this patient has a deletion that results in an abnormal, short Cl INH mRNA, in addition to a normal message. The deletion in the mRNA corresponds to exon VII (22). This abnormality almost certainly results from a deletion in the $\mathrm{Cl}$ INH gene that includes exon VII, rather than a splicing defect. This conclusion is consistent with the previous finding that the abnormal C1 INH mRNA in this patient was $\sim 0.2-\mathrm{kb}$ shorter than the normal message (exon

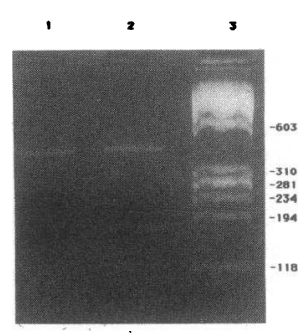

Figure 4. PCR amplification of the abnormal mRNA segment. Synthesized DNA fragments from RNA derived from the hepatoma cell line, HepG2 (lane 1), and RNA from patient's monocytes (lane 2) were amplified using PCR. Amplification of patient's RNA yielded two DNA bands (lane 2$)(\sim 380$ and $160 \mathrm{bp}$ ), one of which was identical in size to that seen in lane 1. Lane 3 is an Hae III digest of $\phi$ $\times 174$ DNA. 
984

$$
\begin{aligned}
& \text { AAC TCA GTT ATA AAA GTG CCC ATG ATG AAT AGC AAG AAG TAC CCT } \\
& 1029 \\
& \text { GTG GCT CAT TTC ATT GAC CAA ACT TTG AAA GCC AAG+AAT TCT TCG } \\
& 1294 \\
& \text { ATT TTT CTT ATG ACC TTA ACC TGT GTG GGG TGA CAG AGG AC C CAG } \\
& 1339 \\
& \text { ATC TTC AGG TTT CTG CGA TGC AGC AC }
\end{aligned}
$$

Figure 5. Sequence analysis of the 160-bp DNA fragment synthesized using PCR. Nucleotides 1,065-1,284 of the normal cDNA were deleted. The splice site between nucleotides 1,064 and 1,285 is indicated by the dagger. The premature termination codon created by the frame shift resulting from the deletion is indicated by the asterisk. The sequences used for construction of oligonucleotide primers for PCR are underlined.

VII is 220 bp long). From the limited information currently available, partial deletions within the $\mathrm{C} 1$ INH gene probably account for $15-20 \%$ of families with type I HANE $(10,17,32$, 33). It is possible, as suggested by Carter et al. (22), that these deletions are related to the presence of Alu I repeats (34) within some of the introns in the $\mathrm{Cl}$ INH gene. These repeats are thought to predispose to deletions and insertions as a result of unequal crossing over. The deletion described here is consistent with this explanation because Alu I repeats are present at least in the intron preceding exon VII (22). Sequence analysis of genomic clones of the abnormal gene from this patient and of the intron after exon VII in the normal gene will be required to confirm this suggestion.

Southern blot analysis after digestion with Pst I and Sac I detected RFLP using the full-length $\mathrm{C} 1 \mathrm{INH}$ cDNA as a probe. All bands that hybridized with probe 1,114-1,284 were about half the intensity of the equivalent bands from control individuals. These results strongly suggest that one of the $\mathrm{Cl}$ INH allelles in this patient has a deletion that includes at least the nucleotides corresponding to this probe, which is contained within exon VII. As described in Results, the $6.9-\mathrm{kb}$ polymorphic fragment seen in a Sac I digest of the patient's DNA, is probably derived from the 5.8- and 3.2-kb Sac I fragments. This suggests that, if the polymorphism is the result of a deletion, this deletion must be $\sim 2 \mathrm{~kb}$ long. This hypothesis must, however, be confirmed by sequence analysis of appropriate $\mathrm{Cl}$ INH genomic clones from the patient. RFLPs were again observed using probe $1,289-1,810$. This probe is contained entirely within exon VIII (22). Because it detects an RFLP, this suggests that it is outside, but near, the deletion. The $3^{\prime}$ end of the deletion, therefore, does not extend through exon VIII. A genomic DNA library has been constructed from this patient's DNA, and clones corresponding to both the normal and abnormal $\mathrm{Cl}$ INH allelles have been isolated. Preliminary analyses of these clones are consistent with the above hypothesis. Southern blot analysis and detailed restriction mapping confirm that the abnormal allelle contains no DNA corresponding to exon VII and that the deletion is $\sim 2 \mathrm{~kb}$ in length (unpublished data).

The patient's abnormal Cl INH mRNA that hybridized with full-length $\mathrm{C} 1$ INH cDNA probes, did not hybridize with probe 1,114-1,284, indicating that at least this segment of exon VII was deleted. Using this information, oligonucleotide primers for PCR were constructed to amplify the sequence between nucleotides 984 and 1,364. Using the patient's mRNA, this resulted in two DNA fragments, one of which was $\sim 380$ bp long, as would be predicted for the normal message, whereas the other was 220 bp shorter. Sequence analysis of these amplified DNA fragments confirmed that the shorter one had a deletion that corresponded to exon VII. Thus, although the patient probably has a deletion in the $\mathrm{C} 1 \mathrm{INH}$ gene that includes exon VII (and portions of both flanking introns), transcription and RNA processing apparently proceed normally to produce the small mRNA.

The patient has type I HANE. Although she has an abnormal C1 INH mRNA, no abnormal C1 INH protein has been detected in her serum (8). In addition, no abnormal $\mathrm{Cl}$ INH protein was synthesized by cultured monocytes from this patient (8). Intracellular $\mathrm{C} 1 \mathrm{INH}$ levels in these cultured monocytes were $\sim 50 \%$ of normal, as were the intracellular Cl INH levels in monocytes from the other type I patients. A pulsechase experiment with this patient's monocytes revealed no difference in the kinetics of synthesis or secretion of $\mathrm{C} 1 \mathrm{INH}$ as compared with other type I patients or with normals (8). Thus, no truncated protein that might result from translation of the abnormal mRNA has been detected, and there is no apparent abnormality in transcription or translation of the normal allelle. Deletion of the nucleotides corresponding to exon VII in the abnormal $\mathrm{Cl}$ INH mRNA created a frame-shift resulting in a premature termination codon at the 14th triplet after the deletion (Fig. 5). There are at least three potential explanations for the inability to detect an abnormal $\mathrm{Cl}$ INH protein in her serum. It is possible that the abnormal mRNA is not translated. If translation occurs, a prematurely terminated protein would result ( 334 residues compared with 478 residues for the normal protein). It is very likely that this polypeptide would be rapidly degraded intracellularly. In vitro translation experiments will be required to answer these questions. Finally, it is possible that the mRNA itself is unstable. Northern blot analysis is consistent with this possibility. Although the original preparations of RNA from the patient's monocytes revealed equal amounts of normal and small $\mathrm{Cl}$ INH mRNA, most subsequent preparations have shown diminished quantities of the smaller message (Fig. 3).

It is noteworthy that the abnormally short $\mathrm{C} 1 \mathrm{INH}$ mRNA in this patient is detectable, although the amount is less than the normal message. Mutations that cause premature termination usually are associated with a marked quantitative decrease in the amount of specific mRNA $(35,36)$. It has been suggested that this kind of mutation may affect intranuclear RNA stability or nuclear to cytoplasmic transport $(37,38)$. Although abnormal specific mRNA has been associated with some genetic diseases, most mutations described have been point mutations or some other mutation that affects the RNA splicing process. Such abnormal mRNAs usually have been detectable only by analyses such as $S_{1}$ nuclease protection assays or sequence analysis $(39,40)$. Yang et al. reported an abnormally large message in a patient with hypoxanthine-guanine phosphoribosyl transferase deficiency due to gene duplication (38). In instances of deletions large enough to include an entire exon, mRNA usually is not detected $(12,41,42)$. Therefore, further analysis of the abnormality in this patient, including the sequence of the relevant portion of the abnormal $\mathrm{Cl}$ INH gene, and in vitro expression studies, may shed light on the requirements for normal transcription and translation. 


\section{Acknowledgments}

The authors wish to thank Dr. Fred S. Rosen for allowing us to study his patient, and for many helpful discussions. We also thank Dr. A. S. Whitehead and Dr. Kamyar Zahedi for assistance in synthesis of oligonucleotide primers.

This work was supported by U. S. Public Health Service grants HD-22082 and by the March of Dimes Birth Defect Foundation grant 1-775. This work was done during the tenure of an Established Investigatorship of the American Heart Association (Dr. Davis), and with funds contributed in part by the American Heart Association Massachusetts Affiliate, Inc.

\section{References}

1. Donaldson, V. H., and F. S. Rosen. 1964. Action of complement in hereditary angioneurotic edema: the role of $\mathrm{Cl}$ esterase. J. Clin. Invest. 43:2204-2213.

2. Landerman, N. S., M. E. Webster, E. L. Becker, and H. E. Ratcliffe: 1962. Hereditary angioneurotic edema. II. Deficiency of inhibitor for serum globulin permeability factor and/or plasma kallikrein. J. Allergy. 33:330-341.

3. Donaldson, V. H., and F. S. Rosen. 1966. Hereditary angioneurotic edema: a clinical survey. Pediatrics. 37:1017-1027.

4. Frank, M. M., J. A. Gelfand, and J. P. Atkinson. 1976. Hereditary angioedema: the clinical syndrome and its management. Ann. Intern. Med. 84:580-593.

5. Gelfand, J. A., R. J. Sherins, D. W. Alling, and M. M. Frank. 1976. Treatment of hereditary angioedema with danazol. Reversal of clinical and biochemical abnormalities. N. Engl. J. Med. 295:14441448.

6. Rosen, F. S., C. A. Alper, J. Pensky, M. R. Klemperer, and V. H. Donaldson. 1971. Genetically determined heterogeneity of the $\mathrm{Cl}$ esterase inhibitor in patients with hereditary angioneurotic edema. $J$. Clin. Invest. 50:2143-2149.

7. Gadek, J. E., S. W. Hosea, J. A. Gelfand, and M. M. Frank. 1979. Response of variant hereditary angioedema phenotypes to danazol therapy. Genetic implications. J. Clin. Invest. 64:280-286.

8. Cicardi, M., T. Igarashi, F. S. Rosen, and A. E. Davis III. 1987. Molecular basis for the deficiency of complement 1 inhibitor in type I hereditary angioneurotic edema. J. Clin. Invest. 79:698-702.

9. Quastel, M., R. Harrison, M. Cicardi, C. A. Alper, and F. S. Rosen. 1983. Behavior in vivo of normal and dysfunctional $C 1$ inhibitor in normal subjects and patients with hereditary angioneurotic edema. J. Clin. Invest. 71:1041-1046.

10. Cicardi, M., T. Igarashi, M. S. Kim, D. Frangi, A. Agostoni, and A. E. Davis III. 1987. Restriction fragment length polymorphism of the $\mathrm{Cl}$ inhibitor gene in hereditary angioneurotic edema. J. Clin. Invest. 80:1640-1643.

11. Nienhuis, A. W., N. P. Anagnou, and T. J. Ley. 1984. Advances in thalassemia research. Blood. 63:738-758.

12. Wilson, J. M., J. T. Stout, T. D. Palella, B. L. Davidson, W. N. Kelley, and C. T. Caskey. 1986. A molecular survey of hypoxanthineguanine phosphoribosyltransferase deficiency in man. J. Clin. Invest. 77:188-195.

13. Prochownik, E. V., S. Autonarakis, K. A. Bauer, R. D. Rosenberg, E. R. Fearon, and S. H. Orkin. 1983. Molecular heterogeneity of inherited antithrombin III deficiency. $N$. Engl. J. Med. 308:14491552.

14. Gitschier, T., W. I. Wood, E. G. D. Tuddenham, M. A. Shuman, T. M. Goralka, E. Y. Chen, and R. M. Lawn. 1985. Detection and sequence of mutations in the factor VIII gene of haemophiliacs. Nature (Lond.). 315:427-430.

15. Donaldson, V. H., R. A. Harrison, F. S. Rosen, D. H. Bing, G. Kindness, J. Canar, C. J. Wagner, and S. Awad. 1985. Variability in purified dysfunctional $\mathrm{Cl}$-inhibitor proteins from patients with heredi- tary angioneurotic edema: functional and analytical gel studies. $J$. Clin. Invest. 75:124-132.

16. Harpel, P. C., T. E. Hugli, and N. R. Cooper. 1975. Studies on human plasma $\mathrm{Cl}$ inactivator-enzyme interactions. II. Structural features of an abnormal $\mathrm{Cl}$ inactivator from a kindred with hereditary angioneurotic edema. J. Clin. Invest. 55:605-611.

17. Cicardi, M., T. Igarashi, M. S. Kim, D. Frangi, A. Agostoni, F. S. Rosen, and A. E. Davis III. 1987. Genetic heterogeneity of hereditary angioneurotic edema. Clin. Res. 35:606a. (Abstr.)

18. Davis, A. E. III, A. S. Whitehead, R. A. Harrison, A. Dauphinais, G. A. P. Bruns, M. Cicardi, and F. S. Rosen. 1986. Human Cl inhibitor: characterization of cDNA clones and localization of the gene to chromosome 11. Proc. Natl. Acad. Sci. USA. 83:3161-3165.

19. Whitehead, A. S., D. E. Woods, E. Fleishnick, J. E. Chin, E. J. Yunis, A. J. Katz, P. S. Gerald, C. A. Alper, and H. R. Colten. 1984. DNA polymorphism of the $\mathrm{C} 4$ genes: a new marker for analysis of the major histocompatibility complex. N. Engl. J. Med. 310:88-91.

20. Wahl, G. M., M. Stern, and G. R. Stark. 1979. Efficient transfer of large DNA fragments from agarose gels to diazobenzoloxymethal paper and rapid hybridization using dextran sulfate. Proc. Natl. Acad. Sci. USA. 76:3683-3687.

21. Bock, S. C., K. Skriver, E. Nielsen, M. C. Thogersen, B. Wiman, V. H. Donaldson, R. L. Eddy, J. Marrinan, E. Radziejewska, R. Huber, T. Shows, and S. Magnusson. 1986. Human C1 inhibitor: primary structure, cDNA cloning and chromosomal localization. Biochemistry. 25:4292-4301.

22. Carter, P. E., B. Dunbar, and J. E. Fothergill. 1988. Genomic and CDNA cloning of the human $\mathrm{Cl}$ inhibitor: Intron-exon junctions and comparison with other serpins. Eur. J. Biochem. 173:163-169.

23. Feinberg, A. P., and B. Vogelstein. 1983. A technique for radiolabelling DNA restriction endonuclease fragments to high specific activity. Anal. Biochem. 132:6-13.

24. Einstein, L. P., E. E. Schneeberger, and H. R. Colten, H. R. 1976. Synthesis of the second component of complement by long-term primary culture of human monocytes. J. Exp. Med. 143:114-126.

25. Chirgwin, J. M., A. E. Przybla, R. J. MacDonald, and W. J. Rutter. 1979. Isolation of biologically active ribonucleic acid from sources enriched in ribonuclease. Biochemistry. 18:5294-5299.

26. Thomas, P. S. 1980 . Hybridization of denatured RNA and small DNA fragments transferred to nitrocellulose. Proc. Natl. Acad. Sci. USA. 77:5201-5205.

27. Mullis, K. B., and F. A. Faloona. 1987. Specific synthesis of DNA in vitro via a polymerase catalyzed chain reaction. Methods Enzymol. 155:335-350.

28. Saiki, R. K., S. Schart, F. Faloona, K. B. Mullis, G. T. Horn, H. A. Erlich, and N. Arnheim. 1985. Enzymatic amplification of $\beta$ globin genomic sequence and restriction site analysis for diagnosis of sickle cell anemia. Science (Wash. DC). 230:1350-1354.

29. Morris, K. M., D. P. Aden, B. B. Knowles, and H. R. Colten. 1982. Complement biosynthesis by human hepatoma derived cell line HepG2. J. Clin. Invest. 70:906-913.

30. Saiki, R. K., D. H. Gelfand, S. Stoffel, S. J. Scharf, R. Higuchi, G. T. Horn, K. B. Mullis, and H. A. Erlich. 1988. Primer-directed enzymatic amplification of DNA with a thermostable DNA polymerase. Science (Wash. DC). 239:487-491.

31. Sanger, F., S. Nicklen, and R. A. Coulson. 1977. DNA sequencing with chain-terminating inhibitors. Proc. Natl. Acad. Sci. USA. 74:5463-5467.

32. Stoppa-Lyonnet, D., M. Tosi, J. Laurent, A. Sobel, G. Lagrue, and T. Meo. 1987. Altered $\mathrm{Cl}$ inhibitor genes in type $\mathrm{I}$ hereditary angioedema. $N$. Engl. J. Med. 317:1-6.

33. Stoppa-Lyonnet, D., T: Meo, J. Laurent, and M. Tosi. 1987. Heterogeneity of $\mathrm{Cl}$ inhibitor gene alterations in type I hereditary angioedema. Complement. 4:229. (Abstr.).

34. Jelinek, W. R., and C. D. Schmid. 1982. Repetitive sequences in eukaryotic DNA and their expression. Annu. Rev. Biochem. 51:813-844. 
35. Benz, E. J., Jr., B. G. Forget, D. G. Hillman, M. Cohen-Sofal, J. Pritchard, C. Cavallesco, W. Prensky, and D. Housman. 1978. Variability in the amount of $\beta$-globin mRNA in $\beta^{\circ}$ thalassemia. Cell. 14:299-313.

36. Maquat, L. E., A. J. Kinniburgh, E. A. Rachmilewitz, and J. Ross. 1981. Unstable $\beta$-globlin mRNA in mRNA-deficient $\beta^{\circ}$ thalassemia. Cell. 27:543-553.

37. Takeshita, K., B. G. Forget, A. Scarpa, and E. J. Benz, Jr. 1984. Intranuclear defect in $\beta$ globin mRNA accumulation due to a premature termination codon. Blood. 64:13-22.

38. Humphries, R. K., T. J. Ley, N. P. Anagnou, A. W. Baur, and A. W. Nienhuis. 1984. $\beta^{\circ}-39$ Thalassemia gene: a premature termination codon causes $\beta$ mRNA deficiency without affecting cytoplasmic $\beta$ mRNA stability. Blood. 64:23-32.
39. Adrian, G. S., D. A. Wiginton, and J. J. Hutton. 1984. Structure of adenosine deaminase mRNAs from normal and adenosine deaminase-deficient human cell lines. Mol. Cell. Biol. 4:1712-1717.

40. Ley, T. J., N. P. Anagnou, G. Pepe, and A. W. Nienhuis. 1982. RNA processing errors in patients with $\beta$-thalassemia. Proc. Natl. Acad. Sci. USA. 79:4775-4779.

41. Yang, T. P., P. I. Patel, A. C. Chinault, J. T. Stout, L. G. Jackson, B. H. Hildebrand, and C. T. Caskey. 1984. Molecular evidence for new mutation at the HPRT locus in Lesch-Nyhan patients. Nature (Lond.). 310:412-414.

42. Orkin, S. H., R. Kolodner, A. Michelson, and R. Husson. 1980. Cloning and direct examination of a structurally abnormal human $\beta^{\circ}$-thalassemia globin gene. Proc. Natl. Acad. Sci. USA. 77:3558-3562. 